\title{
Effects of Liming on the Growth and Nutritional Status of Crambe (Crambe abyssinica Hochst)
}

\author{
Willian Yuki Watanabe de Lima Mera \\ Dept. of Soil Sciences, Federal Rural University of Amazonia \\ Capanema, Pará, Brazil \\ E-mail: willian.watanabe.mera@gmail.com \\ Ismael de Jesus Matos Viégas \\ Dept. of Soil Sciences, Federal Rural University of Amazonia \\ Capanema, Pará, Brazil \\ E-mail: matosviegas@hotmail.com
}

Jessivaldo Rodrigues Galvão (Corresponding author)

Dept. of Soil Sciences, Federal Rural University of Amazonia

Belém, Pará, Brazil

E-mail: jessigalvao50@gmail.com

Tiago Kesajiro Moraes Yakuwa

Dept. of Soil Sciences, Federal Rural University of Amazonia

Belém, Pará, Brazil

E-mail: tiagokmyakuwa@gmail.com

Alasse Oliveira da Silva

Dept. of Soil Sciences, Federal Rural University of Amazonia

Capanema, Pará, Brazil

E-mail: alasse.oliveira77@gmail.com 
Dioclea Almeida Seabra Silva

Dept. of Soil Sciences, Federal Rural University of Amazonia

Capanema, Pará, Brazil

E-mail: dioclea.seabra@ufra.edu.br

\author{
Ricardo Shigueru Okumura \\ Dept. of Soil Sciences, Federal Rural University of Amazonia \\ Parauapebas, Pará, Brazil \\ E-mail: ricardo_okumura@ hotmail.com
}

Jorge Cardoso de Azevedo

Dept. of Animal Production Health, Federal Rural University of Amazonia

Belém, Pará, Brazil

E-mail: jorge.azevedo1@gmail.com

Received: Jan. 3, 2020

doi:10.5296/jas.v8i2.16176
Accepted: Mar. 25, 2020 Published: Apr. 22, 2020

URL: https://doi.org/10.5296/jas.v8i2.16176

\begin{abstract}
Crambe cultivation has expanded in Brazil. The species is a promising alternative for biodiesel production since its seed contain great amounts of oil. Nevertheless, only few studies have focused on the growth and nutritional requirements of crambe cultivated in acidic soils. Thus, this study aimed to evaluate the effects of liming on the growth and nutrient accumulation of crambe cultivated in a Yellow Latosol of medium texture. The experiment was carried out using a randomized complete block design. The treatments consisted of different soil base saturation levels $(0 \%, 20 \%, 40 \%, 60 \%$ and $80 \%)$ with five replications. Plant height, leaf length, leaf width and the number of seeds were evaluated 90 days after planting. The plant material was separated into leaves, stem, seeds and roots, which were oven dried at $70{ }^{\circ} \mathrm{C}$ until constant weight. Analysis of variance was performed, followed by data regression when significant at $5 \%$ probability level by the $\mathrm{F}$ test. Crambe responded positively to liming in the soil under study at a base saturation of $56.95 \%$ as a function of the biometric variables. The increase in the base saturation of the soil to up to $60 \%$ promoted a drastic reduction in plant
\end{abstract}


growth and, therefore, in the final grain yield. The decreasing order of the leaf nutritional content at $56.95 \%$ base saturation was: $\mathrm{N}>\mathrm{Ca}>\mathrm{K}>\mathrm{Mg}>\mathrm{S}>\mathrm{P}>\mathrm{Fe}>\mathrm{B}>\mathrm{Mn}>\mathrm{Zn}>\mathrm{Cu}$.

Keywords: acidic soil; base saturation, plant growth; nutrient accumulation

\section{Introduction}

Crambe (Crambe abyssinica Hochst), which belongs to the Brassicaceae family, is a species of great adaptability to different edaphoclimatic conditions, presenting rusticity, precocity, tolerance to water deficit, short production cycle, as well as resistance to pests (Agrotis spp., Spodoptera spp. e B. brassicae) and diseases (Alternaria brassicicola and TuMV) (Colodetti et al., 2012). Thus, the cultivation of crambe represents a great alternative for crop rotation, with a high potential for expansion for the growing period, which is different from other temporary crops, since the sowing season does not coincide with those of grain crops, such as soybeans and maize. Since the creation of the Brazilian National Program for the use and production of biodiesel (PNPB), in 2004, studies focusing on crambe have shown its potential for biodiesel production, since its seeds can present up to $36 \%$ of oil content (Donadon et al., 2015), producing high quality biodiesel (Rosa et al., 2014).

Crambe cultivation can be compromised in the presence of aluminum $\mathrm{Al}^{3+}$ (Bassegio et al., 2016; Rosmaninho et al., 2019) and low levels of calcium (Ca) and magnesium ( $\mathrm{Mg}$ ) in the soil. Successful crambe cultivation has been carried out at $\mathrm{pH}$ values higher than 5.8 in eutrophic soils (Pitol et al., 2010). According to Janegitz et al. (2010) and Silva et al. (2017), suitable base saturations for the development and production in medium and sandy textured soils are $\mathrm{V} \%=50-65 \%$ and $\mathrm{V} \%=70 \%$, respectively. However, there is no specific recommendation for the crop, and only few scientific studies have focused on showing the amount of essential nutrients required by crambe (Alves et al., 2016).

The soils of the Amazon region are mostly constituted by Oxisols and Ultisols (Souza et al., 2018), which present high acidity, high exchangeable Al contents, low availability of basic cations, such as $\mathrm{Ca}$ and $\mathrm{Mg}$, low availability of phosphorus $(\mathrm{P})$ and micronutrients, such as boron (B) and cupper (Cu) (Veloso et al., 2001). Thus, since plant growth is limited on these soils, liming is considered one of the least expensive and effective practices to raise the soil $\mathrm{pH}$, as well as its cation exchange capacity and nutrient availability (Li et al., 2019). Under soil acidity conditions, lime application promotes increases in soil $\mathrm{pH}$, as well as $\mathrm{Al}^{3+}$ neutralization and $\mathrm{Ca}$ and $\mathrm{Mg}$ supply, since the lime dissolution products $\left(\mathrm{CaCO}_{3}\right)$ react with soil colloids, displacing $\mathrm{Ca}$ and $\mathrm{Mg}$ to solution; $\mathrm{CaCO}_{3}$ and $\mathrm{MgCO}_{3}$ react with $\mathrm{H}^{+}$, releasing $\mathrm{H}_{2} \mathrm{O}$ and $\mathrm{CO}_{2}$ (Holland et al., 2018), while $\mathrm{Al}^{3+}$ is precipitated by reaction with $\mathrm{OH}^{-}$, forming aluminum hydroxide (Melo et al., 2019).

This study evaluated the effects of liming on growth and nutrient accumulation of crambe in Yellow Latosol soil under greenhouse conditions at Igarapé-Açu, Federal Rural University of Amazonia, Brazil. 


\section{Material and Methods}

\subsection{Experimental Area}

The experiment was carried out under greenhouse conditions at the experimental farm of Igarapé-Açu (FEIGA) from the Federal Rural University of Amazonia, Brazil. The soil is classified as Latosol of medium texture (Embrapa, 2018), and it was collected in the $0-20 \mathrm{~cm}$ deep layer. The chemical attributes of the soil prior to the experiment and after liming application were evaluated using the methodology described by Embrapa (1997) and are shown in Table 1.

Table 1. Soil chemical attributes prior to the experiment and after liming application.

\begin{tabular}{|c|c|c|c|c|c|c|c|c|c|c|c|c|c|c|}
\hline Treatment & $\mathrm{pH}$ & $\mathrm{C}$ & $\mathrm{OM}$ & $\mathrm{P}$ & $\mathrm{K}$ & $\mathrm{Na}$ & $\mathrm{Al}$ & $\mathrm{Ca}$ & $\mathrm{Ca}+\mathrm{Mg}$ & $\mathrm{H}+\mathrm{Al}$ & \multicolumn{2}{|c|}{ CEC } & \multicolumn{2}{|c|}{ Saturation } \\
\hline & $\mathrm{H}_{2} \mathrm{O}$ & \multicolumn{2}{|c|}{----g kg-1---- } & \multicolumn{3}{|c|}{$--m g d^{-3}--$} & \multicolumn{4}{|c|}{---------cmolc $\mathrm{dm}^{-3}$} & $\begin{array}{l}\text { Tot. } \\
\text { cmol }\end{array}$ & $\begin{array}{l}\text { Efet. } \\
/ \mathrm{dm}^{3}\end{array}$ & $\begin{array}{l}\text { Base } \\
\text { V\% }\end{array}$ & $\begin{array}{c}\mathrm{Al} \\
\mathrm{M} \%\end{array}$ \\
\hline \multicolumn{15}{|c|}{ Prior to the experiment } \\
\hline & 5.2 & --- & 15.43 & 2 & 15 & 7 & 0.4 & 0.6 & 1 & 4.13 & 6.27 & --- & 17.05 & 27.23 \\
\hline \multicolumn{15}{|c|}{ After liming application } \\
\hline $0 \%$ & 5.54 & 13.93 & 24.03 & 14 & 44 & 12 & 0.06 & 2.56 & 3.28 & 3.32 & 6.77 & 3.51 & 50.93 & 1.71 \\
\hline $20 \%$ & 5.04 & 15.25 & 26.31 & 16 & 46 & 13 & 0.07 & 2.87 & 4.12 & 3.25 & 7.54 & 4.36 & 56.95 & 1.60 \\
\hline $40 \%$ & 6.39 & 14.24 & 24.56 & 15 & 41 & 12 & 0.04 & 3.01 & 4.08 & 3.40 & 7.64 & 4.28 & 55.50 & 0.94 \\
\hline $60 \%$ & 5.94 & 12.58 & 21.70 & 13 & 39 & 13 & 0.02 & 2.99 & 4.19 & 1.36 & 5.70 & 4.36 & 76.17 & 0.46 \\
\hline $80 \%$ & 5.59 & 12.54 & 21.63 & 14 & 43 & 13 & 0.00 & 3.65 & 5.41 & 1.06 & 6.63 & 5.58 & 84.07 & 0.00 \\
\hline
\end{tabular}

\subsection{Experimental Design and Treatments}

The experiment was carried out using a randomized complete block design, consisting of five treatments: $0 \%, 20 \%, 40 \%, 60 \%$ and $80 \%$ of base saturation, with five replications. The calculation to increase the base saturation (Equation 1) was carried out according to the methodology proposed by Raij (2011). The application was performed using dolomitic limestone, consisting of $32 \% \mathrm{CaO}, 15 \% \mathrm{MgO}, 95 \% \mathrm{NP}$ and $91 \%$ of total relative neutralization power (TRNP), which was homogeneously mixed in the soil and incubated for a period of 30 days (Silva et al., 2017). The lime content in the treatments were determined using Eq 1.

$$
L R=\frac{C E C(V 2-V 1)}{T R N P}
$$

$\mathrm{LR}=$ limestone requirement (in $\mathrm{t} \mathrm{ha}^{-1}$ ) with TRNP corrected to $100 \%$;

$\mathrm{CEC}=$ soil cation exchange capacity at $\mathrm{pH} 7.0\left(\right.$ in $\left.\mathrm{cmol}_{\mathrm{c}} \mathrm{dm}^{-3}\right)$, which was calculated by:

$\left[\mathrm{Ca}^{2+}+\mathrm{Mg}^{2+}+\mathrm{K}^{+}+\mathrm{Na}^{+}+\left(\mathrm{H}^{+}+\mathrm{Al}^{3+}\right)\right]$ 
$\mathrm{V}_{2}=$ percentage of base saturation recommended for the crop $(60 \%)$;

$\mathrm{V}_{1}=$ percentage of the initial base saturation of the soil, calculated by: SB x 100/CEC;

$\mathrm{SB}=$ sum of exchangeable bases $\left(\mathrm{Ca}^{2+}+\mathrm{Mg}^{2+}+\mathrm{K}^{+}+\mathrm{Na}^{+}\right)\left(\right.$in $\left.\mathrm{cmol}_{\mathrm{c}} \mathrm{dm}^{-3}\right)$;

TRNP $=$ total relative neutralizing power $(\%)$.

After incubation, two seedlings of crambe from the cultivar FMS Brilhante were planted in pots with a capacity of $5 \mathrm{~kg}$ of air-dried soil. The plants were irrigated to maintain the humidity close to $70 \%$ of the field capacity, which was carried out by weighting the pots. Soil fertilization was carried out by applying $150 \mathrm{mg}$ of $\mathrm{N}$ per $\mathrm{kg}$ of soil (urea), $50 \mathrm{mg}$ of $\mathrm{P}$ per $\mathrm{kg}$ of soil ( $\left.\mathrm{Na}_{2} \mathrm{HPO}_{4}\right), 100 \mathrm{mg} \mathrm{K}$ per $\mathrm{kg}$ of soil $(\mathrm{KCl}), 20 \mathrm{mg}$ of $\mathrm{S}$ per $\mathrm{kg}$ of soil (sodium sulfate), 0.5 $\mathrm{mg}$ of $\mathrm{B}$ per $\mathrm{kg}$ of soil (boric acid), $0.5 \mathrm{mg}$ of $\mathrm{Cu}$ per $\mathrm{kg}$ of soil (copper sulfate), $0.7 \mathrm{mg}$ of $\mathrm{Mn}$ per $\mathrm{kg}$ of soil (manganese sulfate) and $0.6 \mathrm{mg}$ of $\mathrm{Zn}$ per $\mathrm{kg}$ of soil (magnesium sulfate).

After 90 days, plant height and leaf length and width were measured using a metric ruler and the number of leaves was counted (Vasconcelos et al., 2015). The collected material was separated into leaves, stem, seeds and roots, packed in paper bags and dried in a forced air circulation oven at $70{ }^{\circ} \mathrm{C}$ until constant weight, followed by analysis of the contents of the macro and micronutrients (Miyazawa et al., 1992).

The crop productivity, foliar macro and micronutrient contents, and leaf cation contents (LCC) were calculated using Equations 2, 3, 4 and 5, respectively, according to Souza et al. (2014), Silva et al. (2018) and Malavolta (2006).

The calculation to obtain crop productivity were determined using Eq 2.

$$
\text { Productivity }\left(\frac{\mathrm{kg}}{\mathrm{ha}}\right)=\text { number of plants }\left(\frac{\mathrm{pl}}{\mathrm{ha}}\right) \times \text { number of grains }\left(\frac{g r}{\mathrm{pl}}\right) \times \text { grain weight }(\mathrm{Kg})
$$

The calculation to obtain macro (A) and micronutrient (B) leaf accumulation were determined using Eq 3.

$$
\begin{aligned}
& A(g)=\frac{\text { foliar content }(\mathrm{g} / \mathrm{kg}) \times \text { leaf } \text { dry mass }(\mathrm{g})}{1000} \\
& B(\mathrm{mg})=\frac{\text { foliar content }(\mathrm{mg} / \mathrm{kg}) \times \text { Ieaf } d \mathrm{dry} \text { mass }(\mathrm{g})}{1000}
\end{aligned}
$$

The calculation of the leaf cation contents (LCC), in $\mathrm{cmol} \mathrm{kg}^{-1}$ of dry matter were determined using Eq 4.

$$
L L C=\left(\frac{\text { leaf contents of } K}{39.1}+\frac{\text { Ieaf contents of } M g}{12.15}+\frac{\text { Ieaf contents of Ca }}{20.05}\right) \times 1000
$$




\subsection{Statistical Analysis}

The experimental data were initially submitted to the Shapiro-Wilks and Levene tests $(\mathrm{p}<0.01)$ to verify residual normality and homoscedasticity, respectively. After meeting the basic assumptions, the polynomial regression analysis was performed, observing the significance by the F test $(\mathrm{p}<0.05)$ of the analysis of variance, using SPSS 17.0 (SPSS Inc. Released 2008. SPSS Statistics for Windows, Version 17.0 Chicago: SPSS Inc.) and Minitab 18 (Minitab 18 Statistical Software).

\section{Results and Discussion}

The highest plant height was observed for the base saturation percentage of $28 \%$, with a maximum value of $74.83 \mathrm{~cm}$. There were drastic reductions for V\% values higher than $60 \%$ (Figure 1A). As for the number of leaves, the highest value (8.8) was obtained for $\mathrm{V} \%=44 \%$, with a significant reduction in extreme levels of V\% (0 and 80\%) (Figure 1B). Low (or high) $\mathrm{pH}$ values have been reported to interfere with the availability of assimilable forms of some nutrients. Janegitz et al. (2010) and Carvalho et al. (2012) observed smaller numbers of leaves at saturations levels below $20 \%$ and close to $80 \%$.

Regarding leaf width (Figure 1B) and length (Figure 1D), base saturations of 29.50 and 36\% caused leaves to be wider (Y maximum $3.34 \mathrm{~cm}$ ) and longer leaves (with maximum Y of 4.61 $\mathrm{cm}$ ), respectively. The increase in the base saturation to higher values resulted in smaller leaf area. Janegitz et al. (2010) observed similar behavior, in which the plants responded negatively to the saturation increase to values higher than $65 \%$. According to van Kleunen \& Fischer (2005), higher leaf area is important for the better use of light and the capture of atmospheric $\mathrm{CO}_{2}$, which, in addition to other environmental factors, ensure the growth and development of plants.

Regarding productivity (Figure 1E), there was a higher base saturation yield of $29 \%$ (with maximum Y of $2004.76 \mathrm{~kg} \mathrm{ha}^{-1}$ of dry seeds and $2548.9 \mathrm{~kg} \mathrm{ha}^{-1}$ of fresh seeds). The grain yield obtained was similar to that described by Oplinger et al. (1991) for crambe and by Janegitz et al. (2010) for the cultivar FMS brilhante. As for Pitol et al. (2010), the authors obtained lower grain yield averages between 1000 and $1500 \mathrm{~kg} \mathrm{ha}^{-1}$. 

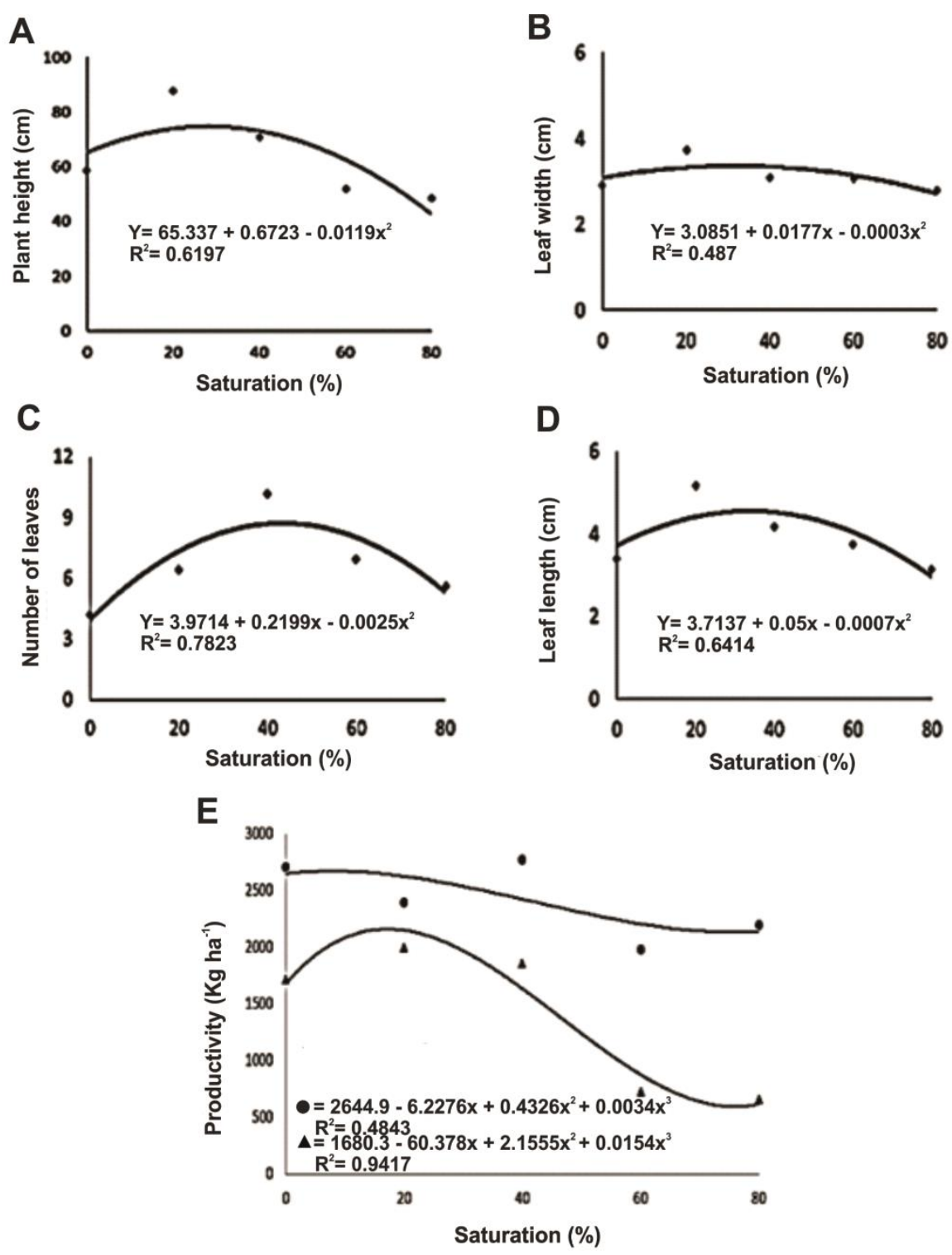

Figure 1. Plant height (A), number of leaves (C), leaf width (B), leaf length (D), fresh (•) and dried $(\boldsymbol{\Delta})$ grain productivity $(\mathrm{E})$ per hectare as a function of base saturation in a Latool of medium texture

As for the contents of the leaf macronutrients (Table 2 and Figure 2), there were increases in the contents of $\mathrm{P}, \mathrm{Ca}, \mathrm{Mg}$ and $\mathrm{S}$ with increasing levels of base saturation. However, the maximum total dry mass production (TDM) was obtained at $\mathrm{V} \%=20 \%$. Thus, considering that the $\mathrm{V} \%$ of maximum TDM is adequate for crambe development, it was verified that the recommended leaf contents, in $\mathrm{g} \mathrm{kg}^{-1}$, were $2.8(\mathrm{P}), 25.5(\mathrm{Ca}), 4.8(\mathrm{Mg})$ and $4.11(\mathrm{~S})$. Malavolta (2006) explained that with the increase in $\mathrm{pH}$, some nutrients become more available to plants. Thus, $\mathrm{pH}$ presents a direct influence on nutrient absorption, in which the greater availability of a nutrient in the soil solution promotes greater absorption by the plant root system.

There were decreases in the contents of $\mathrm{K}$ as a function of saturation increases, which were 
likely due to the inhibitory action of calcium. Marschner (2012) and Malavolta (2006) reported that $\mathrm{K}^{+}$ions present reduced absorption in the presence of high $\mathrm{Ca}^{2+}$ levels because they compete for the same path to cross the plasma membrane. Although there were no visual symptoms of $\mathrm{K}$ deficiency, plants with the lowest nutrient content, especially at $60 \%$ of base saturation (when there were higher $\mathrm{Ca}$ levels in the soil), showed lower growth and productivity when compared with the other treatments.

Another important aspect is the interaction between $\mathrm{N}$ and $\mathrm{K}$, in which, although high levels of $\mathrm{N}$ were obtained in the leaves (up to $53.97 \mathrm{~g} \mathrm{~kg}^{-1}$ ), plant productivity was not negatively affected. Potassium uptake by crambe also provided better plant development, and, consequently, an increase in the contents of dry mass, in which the maximum total dry mass obtained at the base saturation of $20 \%$ coincided with high levels of $\mathrm{N}$ and $\mathrm{K}$ and low levels of Al. Ledur et al. (2016) found similar behavior.

Other nutritional interactions observed in the present study and reported in the literature (Shelp et al., 1995) are related to the antagonist interaction between $\mathrm{N}$ and $\mathrm{B}$. The absorption of $\mathrm{B}$ did not follow the same patterns of the plant growth rate and high nitrogen concentration promoted reduction in B contents. Kojoi et al. (2009) stated that K and S leaf contents in cauliflower were reduced with increasing boron doses, and the results of the present experiment behaved similarly, so that the V\% with maximum TDM presented the leaf content of $139.39 \mathrm{mg} \mathrm{kg}^{-1}$ of B.

Tito et al. (2014) observed a reduction in grain productivity promoted by the low $\mathrm{Cu}$ contents, although no detrimental effect on the growth of crambe plants was identified. However, this fact was not observed in the present study (Figure $2 \mathrm{C}$ ), probably because the micronutrient demand for the crop is low (Soratto et al., 2013), or also due to the excess of N, reported in the literature, as a consequence of the $\mathrm{N}-\mathrm{Cu}$ interaction, in which the highest growth promotes higher micronutrient demand, depending on the soil nutrient availability (Mattos Júnior et al., 2010).

Table 2. Leaf contents of macro and micronutrients and aluminum in normal and deficient crambe plants reported in the literature and values observed in the present study

\begin{tabular}{|c|c|c|c|c|c|c|c|c|c|c|c|c|}
\hline Treatment & $\mathbf{N}$ & $\mathbf{P}$ & $\mathbf{K}$ & $\mathbf{C a}$ & Mg & $\mathbf{S}$ & B & $\mathbf{C u}$ & Fe & Mn & $\mathbf{Z n}$ & Al \\
\hline \multicolumn{13}{|c|}{ 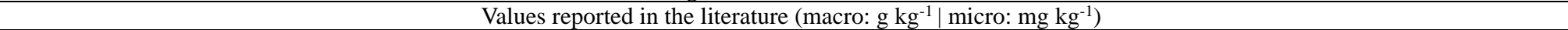 } \\
\hline Normal & $33.1^{\mathrm{b}}$ & $2.2^{\mathrm{b}}$ & $19.4^{\mathrm{c}}$ & $28.4^{\mathrm{b}}$ & $5.3^{\mathrm{b}}$ & $4.4^{\mathrm{a}}$ & $234.4^{\mathrm{c}}$ & $10.3^{\mathrm{b}}$ & $1377^{\mathrm{b}}$ & $83.3^{\mathrm{b}}$ & $71^{\mathrm{c}}$ & $* 143.18$ \\
\hline Deficient & $<20.6^{\mathrm{a}}$ & $<2.1^{\mathrm{c}}$ & $<11.1^{\mathrm{c}}$ & $<16.2^{\mathrm{a}}$ & $<1.8^{\mathrm{c}}$ & $<1.2^{\mathrm{c}}$ & $<69.2^{\mathrm{c}}$ & $<4.8^{\mathrm{b}}$ & $<1.04^{\mathrm{b}}$ & $<30.4^{\mathrm{b}}$ & $<51.8^{\mathrm{e}}$ & --- \\
\hline \multicolumn{13}{|c|}{ 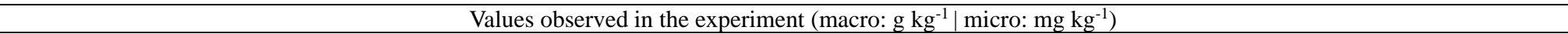 } \\
\hline $\mathbf{0}$ & 62.36 & 2.89 & 14.53 & 26.75 & 4.88 & 3.51 & 214.22 & 0.5 & 920 & 83.55 & 54.19 & 470 \\
\hline 20 & 53.97 & 2.8 & 21.33 & 25.5 & 4.8 & 4.11 & 139.39 & 0.5 & 615 & 68.5 & 56.33 & 207 \\
\hline 40 & 55.41 & 2.77 & 12.53 & 29.25 & 7.33 & 4.41 & 181.57 & 0.5 & 805 & 59.7 & 52.95 & 730 \\
\hline 80 & 53.06 & 4.15 & 12.08 & 33.25 & 8.6 & 4.91 & 153.59 & 2.8 & 2385 & 40.65 & 56.17 & 3475 \\
\hline
\end{tabular}

Source: a Mauad et al. (2013); ${ }^{b}$ Soratto et al. (2013); ${ }^{\circ}$ Brito (2018); ${ }^{\mathrm{d}}$ Rosmaninho et al. (2019); eTito et al. (2016). * Tolerable value

According to Malavolta (2006), the availability of Fe in the soil increases at more acidic $\mathrm{pH}$. Nevertheless, in the present study, a high leaf Fe content $\left(615 \mathrm{mg} \mathrm{kg}^{-1}\right)$ was observed (Figure 2). Crambe demands large amounts of Fe when compared with other grain crops, such as soybean 
(Glycini max) and beans (Phaseolus vulgaris) (Malavolta, 2006; Soratto et al., 2013).

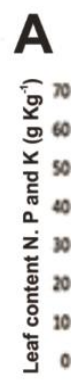

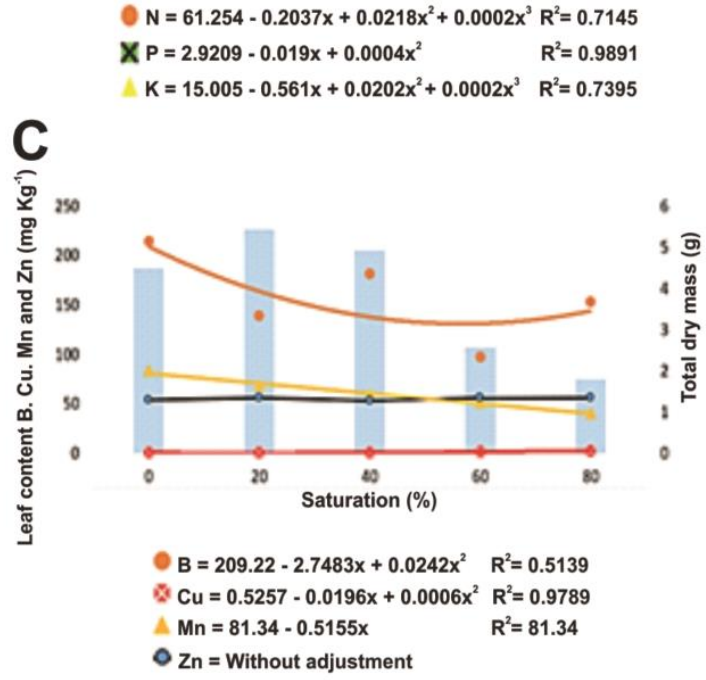

B

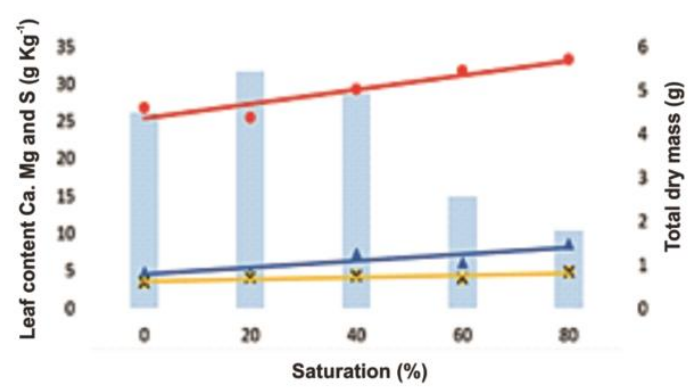

$\mathrm{Ca}=25.45+0.0963 \times \mathrm{R}^{2}=0.8709$

$\Delta \mathrm{Mg}=4.594+0.0441 \times \mathrm{R}^{2}=0.7329$

$X S=3.65+0.0135 x \quad R^{2}=0.6826$

D

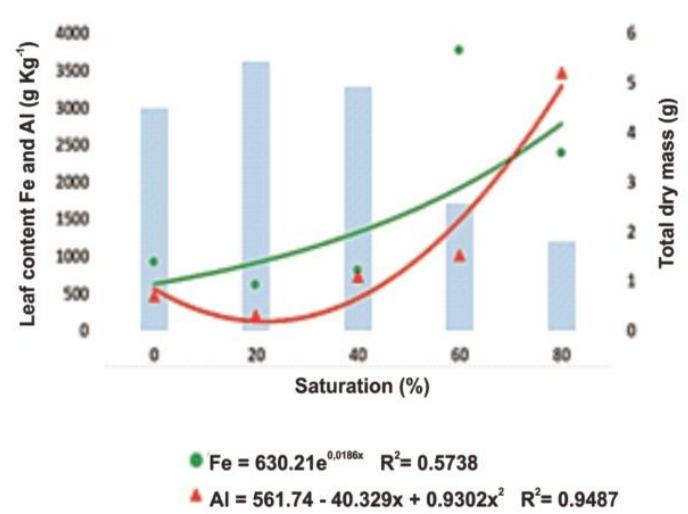

Figure 2. Contents of macronutrients (A and B), micronutrients (C) and aluminum (D) and total dry mass production as a function of base saturation in a Latosol of medium texture

There was an increase in the contents of $\mathrm{Al}$ with the increase of the soil base saturation, with the highest values obtained for $\mathrm{V} \%=60 \%$ and $80 \%$. There was also a reduction of total dry mass, due to a probable nutritional imbalance with the high Al content in the soil. Despite the application of lime in the soil, the insufficient time of reaction of the lime in the soil did not allow the increase of the soil $\mathrm{pH}$ due to the precipitation of $\mathrm{Al}^{3+}$ in the form of $\mathrm{Al}(\mathrm{OH})_{3}$, which presents low solubility (Li \& Johnson, 2016). Malavolta (2006) and Marschner (2012) highlighted the beneficial action of $\mathrm{Al}$ at low concentrations, conferring an increase in plant growth rate. Nevertheless, the same authors pointed out the toxic effect of this element. On the other hand, Rosmaninho et al. (2019) evaluated the tolerance of crambe to aluminum and observed a reduction in root growth, TDM and grain productivity. Colodetti et al. (2015) observed a reduction in the hypocotyl and root length of crambe seedlings, compromising the initial growth of the plant. Costa et al. (2014) observed strong interference in the absorption of $\mathrm{N}$ and K. All of these aspects were also observed in the present study, in which the maximum grain productivity and TDM peaks were obtained at the lowest Al content in the leaves $(207 \mathrm{mg}$ $\left.\mathrm{kg}^{-1}\right)$. The high demands of $\mathrm{N}, \mathrm{Ca}, \mathrm{K}$ and $\mathrm{Fe}$ by crambe were also observed in other grain 


\section{Macrothink}

species, such as soybeans, rapeseed and beans (Malavolta, 2006; Soratto et al., 2013).

Malavolta (2006) described that nutrients such as $\mathrm{Ca}, \mathrm{Mg}$ and $\mathrm{K}$ participate in several mechanisms and structures that are essential to plant development. However, high levels of $\mathrm{Ca}$ and $\mathrm{Mg}$ generate competitive inhibition with $\mathrm{K}$. Although the presence of $\mathrm{K}$ or $\mathrm{Mg}$ at levels less than $25 \%$ of the LCC (Leaf Cation Content) represents a deficiency of these nutrients, it should be adjusted for the specificities of each culture. For crambe, the greater participation of $\mathrm{Ca}$, and, consequently, lower participation of $\mathrm{K}$ and $\mathrm{Mg}$, has been reported by Mauad et al. (2013) and Soratto et al. (2013), via analyzes of the leaf contents. Figures 3 and 4 present fertigrams ${ }^{1}$ with adequate nutrient contents as a function of plant productivity When comparing the percentages of individual participation of these cations in the different treatments, there was a greater presence of $\mathrm{Ca}$ in the leaves, accounting for nearly $60 \%$ of the LCC (Figure 3). On the other hand, in Figure 4, it was verified high presence of $\mathrm{N}$ in the treatments $0 \%$ to $40 \%$ and the exorbitant percentage of $\mathrm{Fe}$ in the treatment $60 \%$. The treatment with $20 \%$ of base saturation was the closest one to the ideal conditions for the good development of the plant.

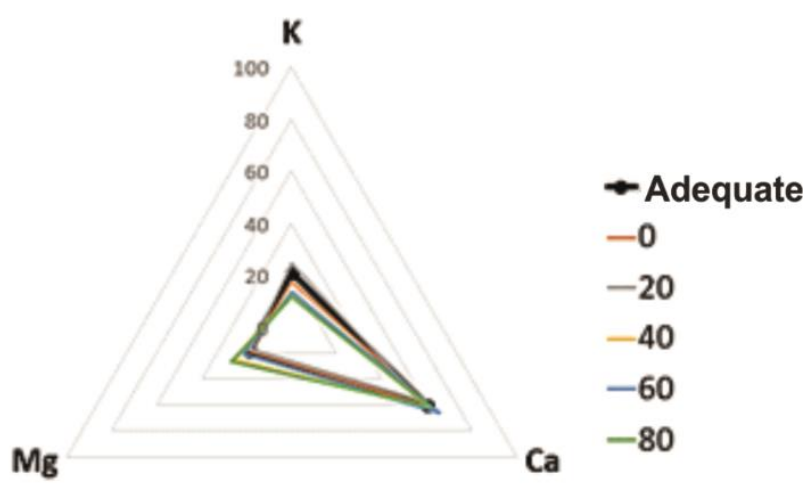

Figure 3. Fertigram of leaf cation contents (LCC) in the different treatments 

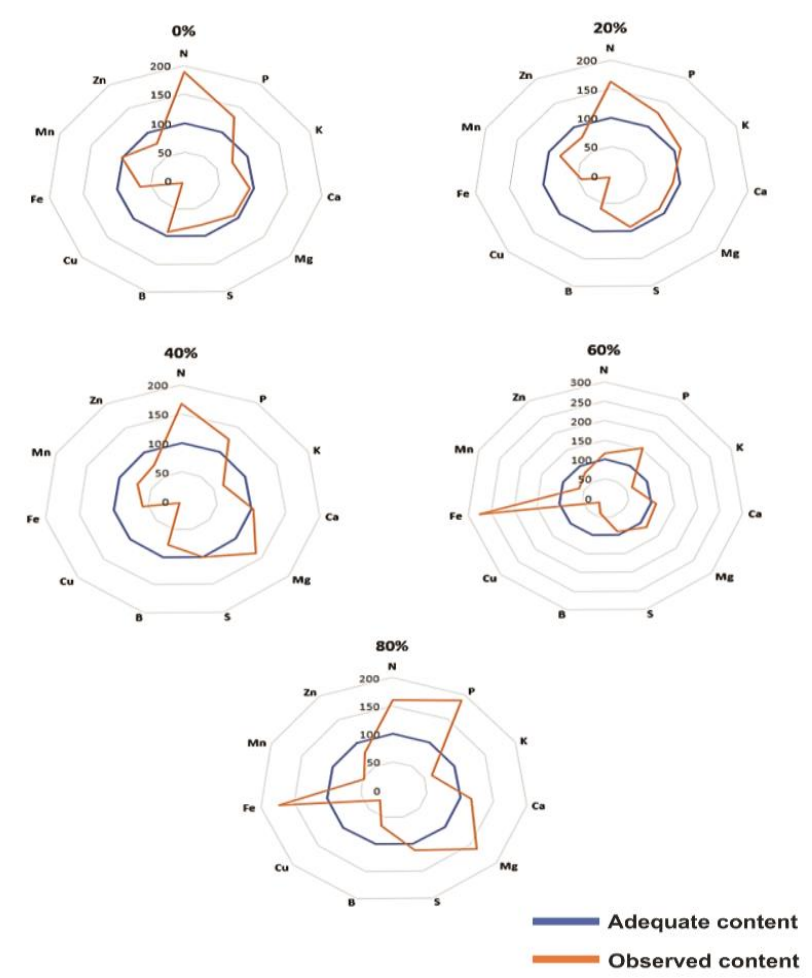

Figure 4. Fertigrams of leaf nutrient contents in the different treatments

${ }^{1}$ Radar graphs with radial divisions plotted for each element, showing the optimal values for the crop and the values obtained in the leaf analysis of the treatments. Points beyond the optimal value polygon indicate excess and points below it (within the polygon) indicate lack (Martinez et al., 1999.

\section{Conclusion}

Crambe plants responded satisfactorily to liming at base saturation levels ranging from $20 \%$ to $56.95 \%$ as a function of the biometric variables evaluated in the Yellow Latosol of medium texture of the present study.

Base saturation levels higher than $60 \%$ promoted drastic reductions in plant growth and grain productivity.

At the base saturation levels of $57 \%$, the following decreasing order of macro and micronutrient contents in the leaf tissues was: $\mathrm{N}>\mathrm{Ca}>\mathrm{K}>\mathrm{Mg}>\mathrm{S}>\mathrm{P}>\mathrm{Fe}>\mathrm{B}>\mathrm{Mn}>\mathrm{Zn}>\mathrm{Cu}$.

\section{Acknowledgements}

The authors would like to thank the Study Group on Plant Nutrition and Soil Fertility (GENFA) from the Amazonian Federal Rural University (UFRA) Campus Capanema for their collaboration.

\section{References}

Alves, J. M., Leandro, W. M., Alves, C. C. F., Carlos, L., Ribon, A. A., \& Fernandes, K. L. (2016). Crambe dry matter and yield under doses of phosphorus and base saturation in the 
Cerrado of Goiás. Revista Brasileira de Engenharia Agrícola e Ambiental, 20, 421-426. https://doi.org/10.1590/1807-1929/agriambi.v20n5p421-426

Bassegio, D., Zanotto, M. D., Santos, R. F., Werncke, I., Dias, P. P., \& Olivo, M. (2016). Oilseed crop crambe as a source of renewable energy in Brazil. Renewable and Sustainable Energy Reviews, 66, 311-321. https://doi.org/10.1016/j.rser.2016.08.010

Brito, K. S. S. B. (2018). Avaliação da fertilidade do Latossolo amarelo textura média para o cultivo de plantas jovens de crambe (Crambe abyssinica Hoscht). Belém: UFRA, 64p.

Carvalho, K. S., Silva, B. E. M., Avelino, C. E., Leite, C. N., \& Koetz, M. (2012). Crambe grown in Cerrado Oxisol submitted to liming. Enciclopédia Biosfera, 8, 552-558.

Colodetti, T. V., Martins, L. D., Rodrigues, W. N., Brinate, S. V. B., \& Tomaz, M. A. (2012). Crambe: General aspects of the agricultural production. Enciclopédia biosfera, 8, 258-269.

Costa, D. P., Costa Júnior, D. S., Hora, V. M., Abreu, C. B., \& Azevedo Neto, A. D. (2014). Aluminum stress affects the growth and NPK accumulation in crambe plants. Enciclopédia Biosfera, 10, 1359-1366.

Donadon, J. R., Bessa, J. F. V., Resende, O., Castro, C. F. S., Alves, R. M. V., \& Silveira, E. V. (2015). Storage of crambe seeds in different containers and environments: Part II-Chemical quality. Revista Brasileira de Engenharia Agrícola e Ambiental, 19, 231-237. https://doi.org/10.1590/1807-1929/agriambi.v19n3p231-237

EMBRAPA. (1997). Manual de métodos de análise de solo. Centro Nacional de Pesquisa de Solos. 2. ed. rev. atual. - Rio de Janeiro, 212 p.

EMBRAPA. (2018). Sistema brasileiro de classificação de solos. 5.ed. Brasília: Embrapa, 590p.

Holland, J. E., Bennett, A. E., Newton, A. C., White, P. J., Mckenzie, B. M., George, T. S., ... Hayes, R. C. (2018). Liming impacts on soils, crops and biodiversity in the UK: A review. Science of the Total Environment, 610/611, 316-332. https://doi.org/10.1016/j.scitotenv.2017.08.020

Janegitz, M. C., Souza-Schlick, Tropaldi, L., \& Cardoso, S. M. (2010). Influence of base saturation on growth and yield of crambe. Cultivando o Saber, 3, 175-182.

Kojoi, C., Mello, S. D. C., Camargo, M. S. D., Fagan, E. B., \& Ribeiro, M. F. (2009). Nitrogen and boron fertilization on hollow stem and yield of cauliflower. Ciência e Agrotecnologia, 3, 13-17. https://doi.org/10.1590/S1413-70542009000100001

Ledur, E. O., Chaves, L. H. G., \& Fernandes, J. D. (2016). Nitrogen and phosphorus on crambe development after off-season corn cultivation. Científica, 44, 263-270. https://doi.org/10.15361/1984-5529.2016v44n2p263-270

Li, W., \& Johnson, C. E. (2016). Relationships among pH, aluminum solubility and aluminum com-plexation with organic matter in acid forest soils of the Northeastern United States. Geoderma, 271, 234-242. https://doi.org/10.1016/j.geoderma.2016.02.030 
Li, Y., Cui, S., Chang, S. X., \& Zhang, Q. (2019). Liming effects on soil pH and crop yield depend on lime material type, application method and rate, and crop species: A global meta-analysis. Journal of Soils and Sediments, 19, 1393-1406. https://doi.org/10.1007/s11368-018-2120-2

Malavolta, E. (2006). Manual de nutrição mineral de plantas. São Paulo: Agronômica Ceres, $631 \mathrm{p}$.

Marschner, H. (2012). Mineral nutrition of higher plants. 3rd edn. London, UK: Academic Press, 672p.

Mattos Junior, D., Ramos, U. M., Quaggio, J. A., \& Furlani, P. R. (2010). Nitrogen and copper for citrus nursery production on two different rootstocks. Bragantia, 69, 135-147. https://doi.org/10.1590/S0006-87052010000100018

Mauad, M., Garcia, R. A., Vitorino, A. C. T., Silva, R. M. M. F., Garbiate, M. V., \& Coelho, L. C. F. (2013). Dry matter and macronutrients accumulation in crambe shoots. Ciência Rural, 43, 771-778. https://doi.org/10.1590/S0103-84782013005000041

Melo, R. M., Vieira, M. C., Carnevali, T. O., Gonçalves, W. V., Torales, E.P., Tolouei, S.E.L., $\&$ Santos, C. C. (2019). Liming and substrate texture affect the development of Campomanesia adamantium (Cambess.) O. Berg. Revista de Ciências Agrárias, 42, 99-108. https://doi.org/10.19084/RCA18283

Miyazawa, M., Pavan, M. A., \& Bloch, M. de F. M. (1992). Análise química de tecido vegetal. Londrina: Iapar, 17p. (Iapar. Circular, 74).

Oplinger, E. S., Oelke, E. A., Kaminski, A. R., Putnam, D. H., Teynor, T. M., Doll, J. D., ... Noetzel, D. M. (1991) Crambe: alternative field crops manual. St. Paul: University of Minnesota, 10p.

Pitol, C., Broch, D. L., \& Roscoe, R. (2010). Crambe: Tecnologia e Produção. Maracaju: Fundação MS, 60p.

Raij, B. van. (2011). Fertilidade do solo e manejo de nutrientes. Piracicaba: International Plant Nutrition Institute, 2011. 420p.

Rosa, H. A., Wazilewski, W. T., Secco, D., Chaves, L. I., Veloso, G., Souza, S. N. M., ... Santos, R. F. (2014). Biodiesel produced from crambe oil in Brazil - A study of performance and emissions in a diesel cycle engine generator. Renewable and Sustainable Energy Reviews, 38, 651-655. https://doi.org/10.1016/j.rser.2014.07.013

Rosmaninho, L. B. C., Dias, L. A. S., Silva, M. F., Vasconcelos, A. A., Santos, W. O., Perez, C. E. A., . . Cardoso, L. G. (2019). Performance of crambe submitted to aluminum stress: An importante oilseed plant. Journal of Agricultural Science, 11, 1-11. https://doi.org/10.5539/jas.v11n2p454

Shelp, B. J., Marentes, E., Kitheka, A. M., \& Vivekanandan, P. (1995). Boron mobility in plants. Physilogoly Plantarum, 356-361. https://doi.org/10.1111/j.1399-3054.1995.tb05323.x 
Silva, S. P., Viégas, I. J. M., Okumura, R. S., Silva, D. A. S., Galvão, J. R., Silva Júnior, M. L., ... Silva, A. O. (2018). Growth and micronutri-ents contents of smell pepper (Capsicum chinense Jac.) submitted to organic fertilizer. Journal of Agricultural Science, 10, 425-435. https://doi.org/10.5539/jas.v10n11p425

Silva, T. R. B., Carraro, T. V., Frigo, P., Barbosa, N. A., Tiburcio, M. G. G., Secco, D., ... Alves, C. Z. (2017). Crambe development under lime application in sandy soil. Acta Iguazu, 6, 59-63.

Soratto, R. P., Souza - Schlick, G. D. D., Fernandes, A. M., \& Souza, E. D. F. C. D. (2013). Effect of fertilization at sowing on nutrition and yield of crambe in second season. Revista $\begin{array}{llllll}\text { Brasileira de } \quad \text { Ciência } & \text { do } & \text { Solo, } & 37, & \text { 658-666. }\end{array}$ https://doi.org/10.1590/S0100-06832013000300012

Souza, E. S., Fernandes, A. R., Braz, A. M. S., Oliveira, F. J., Alleoni, L. R. F., Campos, M. C. C. (2018). Physical, chemical, and mineralogical atributes of a representative group of soils from the eastern Amazon region in Brazil. SOIL, 4, 195-212. https://doi.org/10.5194/soil-4-195-2018

Souza, L. G. M., Lazarini, E., Camargo, F. P., Bossolani, J. W., \& Garcia, A. (2014). Components of production and productivity crambe a function of dose of manure in coverage nitrogen. Enciclopédia Biosfera, 10, 523-531.

Tito, G. A., Chaves, L. H. G., Fernandes, J. D., Monteiro, D. R., \& Vasconcelos, A. C. F. (2014). Effect of copper, zinc, cadmium and choromium in the growth of crambe. Agricultural Sciences, (5), 975-983. https://doi.org/10.4236/as.2014.511105

van Kleunen, M., \& Fischer, M. (2005). Constraints on the evolution of adaptive phenotypic $\begin{array}{lllll}\text { plas-ticity in } \quad \text { plants. } & \text { Phytologist, } & \text { 166, }\end{array}$ https://doi.org/10.1111/j.1469-8137.2004.01296.x

Vasconcelos, A. C. F., Chaves, L. H. G., Souza, F. G., Gheyi, H. R., \& Fernandes, J. D. (2015). Salinity effects on development and productivity of crambe (Crambe abyssinica) under greenhouse conditions. American Journal of Plant Sciences, 6, 839-847. https://doi.org/10.4236/ajps.2015.67091

Veloso, C. A. C., Oeiras, A. H. L., Carvalho, E. J. M., \& Souza, F. R. S. (2001). Response of pine-apple to nitrogen, potassium and limestone in a Yellow Latosol in Brazil. Revista Brasileira de Fruticultura, 23, 396-402. https://doi.org/10.1590/S0100-29452001000200040

\section{Copyright Disclaimer}

Copyright for this article is retained by the author(s), with first publication rights granted to the journal.

This is an open-access article distributed under the terms and conditions of the Creative Commons Attribution license (http://creativecommons.org/licenses/by/4.0/). 